\title{
Integrative review on the incidence of HIV infection and its socio-spatial determinants
}

\author{
Revisão integrativa sobre incidência de infecção pelo HIV e seus determinantes socioespaciais \\ Revisión integrativa sobre incidencia de infección por VIH y sus determinantes socioespaciales
}

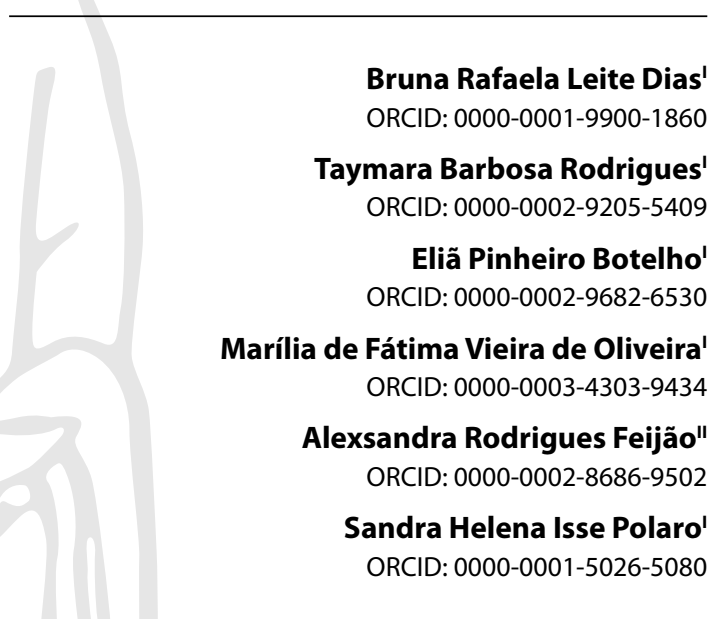

'Universidade Federal do Pará. Belém, Pará, Brazil. "Universidade Federal do Rio Grande do Norte. Natal, Rio Grande do Norte, Brazil.

How to cite this article: Dias BRL, Rodrigues TB, Botelho EP, Oliveira MFV, Feijão AR, Polaro SHI. Integrative review on the incidence of HIV infection and its socio-spatial determinants.

Rev Bras Enferm. 2021;74(2):e20200905.

https://doi.org/10.1590/0034-7167-2020-0905

Corresponding author:

Sandra Helena Isse Polaro

E-mail: shpolaro@hotmail.com

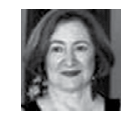

EDITOR IN CHIEF: Antonio José de Almeida Filho ASSOCIATE EDITOR: Priscilla Valladares Broca

Submission: $10-06-2020$

Approval: 11-11-2020

\section{ABSTRACT}

Objectives: to identify the socio-spatial determinants associated with the incidence of infection by the human immunodeficiency virus (HIV) described in national and international literature. Methods: integrative literature review that included original articles indexed in the LILACS, PUBMED, CINAHL, and Scopus databases, from 2015 to 2019. The synthesis of the articles was done in a descriptive manner in two categories according to the type of approach. Results: 13 articles were selected, with a predominance of ecological studies. Regions with deficient access to health services, high population density, higher rates of poverty, intense migratory flow, border areas, as well as precarious socioeconomic conditions, and risk behaviors are associated with higher rates of infection. Final Considerations: the influence of regional inequalities on the incidence of HIV infection is revealed, confirming the relevance of spatial analysis techniques for mapping the distribution of diseases and identifying risk areas.

Descriptors: HIV; Incidence; Spatial Analysis; Public Health Surveillance; Review.

\section{RESUMO}

Objetivos: identificar os determinantes socioespaciais associados à incidência de infecção pelo vírus da imunodeficiência humana (HIV) descritos na literatura nacional e internacional. Métodos: revisão integrativa da literatura que incluiu artigos originais indexados nas bases de dados LILACS, PUBMED, CINAHL e Scopus, no recorte temporal de 2015 a 2019. A síntese dos artigos foi feita de forma descritiva em duas categorias segundo o tipo de abordagem. Resultados: foram selecionados 13 artigos, com predomínio de estudos ecológicos. Regiões com acesso deficiente aos serviços de saúde, alta densidade populacional, maiores índices de pobreza, intenso fluxo migratório, áreas fronteiriças, bem como precárias condições socioeconômicas e comportamentos de risco estão associados às maiores taxas de infecção. Considerações Finais: revela-se a influência das desigualdades regionais sobre a incidência de infecção pelo HIV, ratificando a relevância das técnicas de análise espacial para o mapeamento da distribuição de doenças e identificação de áreas de risco.

Descritores: HIV; Incidência; Análise Espacial; Vigilância em Saúde Pública; Revisão.

\section{RESUMEN}

Objetivos: identificar los determinantes socioespaciales relacionados a la incidencia de infección por virus de la inmunodeficiencia humana $(\mathrm{VIH})$ descritos en la literatura nacional e internacional. Métodos: revisión integrativa de la literatura que incluyó artículos originales indexados en las bases de datos LILACS, PUBMED, CINAHL y Scopus, de 2015 a 2019. Síntesis de artículos hecha de manera descriptiva en dos categorías segundo el tipo de abordaje. Resultados: seleccionados 13 artículos, con predominio de estudios ecológicos. Regiones con acceso deficiente a los servicios de salud, alta densidad poblacional, mayores índices de pobreza, intenso flujo migratorio, áreas fronterizas, bien como precarias condiciones socioeconómicas y comportamientos de riesgo están relacionados a las mayores tasas de infección. Consideraciones Finales: se revela influencia de las desigualdades regionales sobre la incidencia de infección por $\mathrm{VIH}$, ratificando la relevancia de técnicas de análisis espacial para el mapeo de la distribución de enfermedades e identificación de áreas de riesgo. Descriptores: VIH; Incidencia; Análisis Espacial; Vigilancia en Salud Pública; Revisión. 


\section{INTRODUCTION}

Nearing 40 years of its discovery, the human immunodeficiency virus (HIV), which causes acquired immunodeficiency syndrome (AIDS), is still a major challenge for public health worldwide. Despite the $47 \%$ decline in the number of new infections since 1996, there were 37.9 million people living with HIV in 2018, and it is estimated that, since the beginning of the epidemic, 32 million people have died from AIDS-related illnesses. In 2018 alone, approximately 1.7 million new cases of HIV infections and 770 thousand deaths from AIDS-related causes were reported ${ }^{(1)}$.

It is worth noting that incidence rates of HIV infection throughout the world are not homogeneously distributed; and, in this perspective, to explain the spatial distribution of a health problem, the theory of "Social production of health and disease" stands out, linked to lifestyles and based on the social determination of the process of illness, in which historical, economic, social, cultural, biological, environmental, and psychological aspects that characterize a sanitary condition are considered ${ }^{(2)}$.

In short, in the environment, people are exposed to situations that have an influence on their health. In general, these situations do not solely depend on the individuals themselves and their family context, but are also consequences of inefficient political management over the quality of life of the populations, which results in unequal access to public goods and services ${ }^{(3-4)}$.

With that being said, in relation to health, geography is essential for studies of spatial distribution, especially of infectious and parasitic diseases, since it seeks to identify, in the composition of space and in social relations, clarifications relevant to the understanding of the health-disease process ${ }^{(5)}$. In this context, there is a need to identify factors that can justify the epidemiological scenario of HIV infection, with the objective of mapping the epidemic and identifying priority areas for planning strategic actions for promotion, prevention, and control.

\section{OBJECTIVES}

To identify the socio-spatial determinants associated with the incidence of infection by the human immunodeficiency virus (HIV) described in national and international literature.

\section{METHODS}

\section{Ethical aspects}

As the study did not involve human beings, it was not submitted to a Research Ethics Committee.

\section{Type of study}

Integrative literature review, whose method allows to gather and synthesize research results on a given theme or issue, in a systematic and orderly manner, contributing to deepen its knowledge. To build the integrative review, it is necessary to go through six steps: select the hypothesis or research question; establish the criteria for inclusion and exclusion of studies/sampling or literature research; define the information to be extracted from the selected studies/categorization of the studies; evaluate the studies included in the integrative review; interpret the results; and the last step, which is to present the review/synthesis of knowledge $^{(6)}$.

\section{Methodological procedures}

The formulation of the research question was based on the PICO strategy ${ }^{(7)}$, considering that it allows a better definition of the information needed to solve the clinical question under study; and directs the scope of the research by helping to delimit the controlled descriptors for each element of PICO, avoiding unnecessary searches in the databases. Thus, " $\mathrm{P}$ " can be described as a health problem - in this study, HIV; "I" would be the studied intervention or variable of interest, with socio-spatial determinants being admitted; " $C$ " indicates the comparison with another intervention, which was not performed in this study; and " $\mathrm{O}$ " refers to the expected result, the outcome, considering the incidence of infection. Therefore, the following research question was defined: What are the socio-spatial determinants associated with the incidence of HIV infection?

\section{Study scenario}

In order to find the articles, four databases were used: Cumulative Index to Nursing and Allied Health Literature (CINAHL), Literatura Latino-Americana e do Caribe em Ciências da Saúde (LILACS) [Latin American and Caribbean Health Sciences Literature], National Library of Medicine (PubMed), and Scopus (Elsevier).

As inclusion criteria, studies available in full, published in Portuguese, English, or Spanish, were used, with their general or specific objectives addressing social or spatial factors that influence the incidence of HIV infection, published from 2015 to 2019 , considering the inclusion of the infection in the Lista Nacional de Doenças e Agravos de Notificação Compulsória [National List of Compulsory Notification Diseases] in June $2014^{(8)}$. Editorials, dissertations, theses, and review articles were excluded from this study.

\section{Data collection and organization}

The bibliographic survey was carried out by peers in March 2020, through virtual access to the databases. These, in turn, were accessed through the journals portal of the Coordenação de Aperfeiçoamento de Pessoal de Nível Superior (CAPES) [Coordination for the Improvement of Higher Education Personnel], through remote access via the Comunidade Acadêmica Federada (CAFe) [Federated Academic Community], created by the Rede Nacional de Ensino e Pesquisa (RNP) [National Education and Research Network].

As search strategies, the Descritores das Ciências da Saúde (DeCS) [Health Sciences Descriptors], their respective Medical Subject Headings Terms (MeSH Terms), CINAHL terms, and keywords were used. The controlled descriptor "HIV" was selected for the "P" component of the PICO strategy. For components "I" and "O", "Spatial Analysis" and "Incidence", respectively. In addition, as uncontrolled descriptors, it was defined: for the component 
"P", "Human Immunodeficiency Virus"; for "I", "Spatial Behavior"; finally, for "O", "HIV Incidence".

According to the specificities of access to the selected databases, the descriptors were combined with each other at different crossings, using the Boolean operators AND and OR considering each set of terms in the PICO strategy.

Thus, 128 studies were identified, of which, after applying the eligibility criteria, 23 were selected for full reading. These were then imported into Rayyan, which consists of a reference management

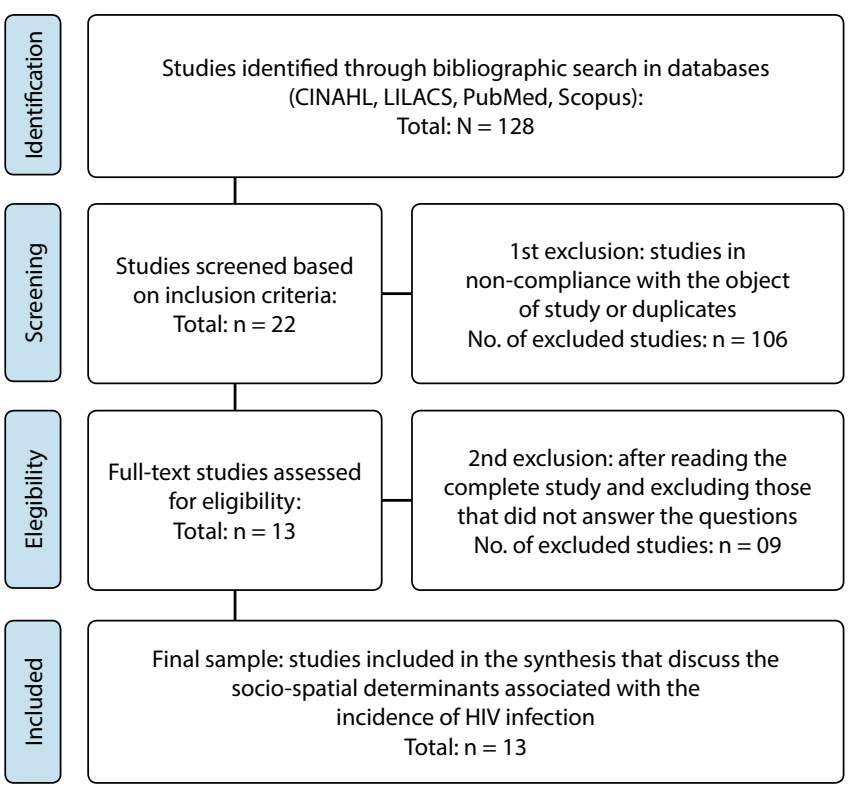

Figure 1 - Study selection flowchart, according to the PRISMA recommendation

application for reviews, ordering results and identifying duplicates in the different databases ${ }^{(9)}$. As shown in Figure 1, according to the recommendation model of the Preferred Reporting Items for Systematic Review and Meta-Analyzes (PRISMA) ${ }^{(10)}, 13$ articles were included in this integrative review.

For the extraction and synthesis of information, an adaptation of a data collection instrument validated by Ursi ${ }^{(11)}$ was applied, with title, year of publication, country, study design, socio-spatial determinants correlated to HIV infection, as well as outcome and conclusions.

\section{Data analysis}

The analysis of the studies was done in a descriptive and qualitative manner, in two categories and according to the type of approach: social determinants and spatial determinants - both associated with the incidence of HIV infection.

\section{RESULTS}

The sample of this review consisted of 13 articles, with publications concentrated in 2019, with a total of 7 (53.84\%) articles; 4 (30.76\%) in 2015; and 1 (7.69\%) in each year of 2016 and 2017. In relation to the country, China stood out with five (38.46\%) productions; three (23.7\%) focused on Brazil; two (15.38\%), South Africa; and one (7.69\%) for each of the others: United States, Libya and Ethiopia.

Regarding the outline of the study, only one (7.69\%) was not considered ecological. Furthermore, in this review, the articles were also labeled as to the level of evidence according to the Oxford Center for Evidence-based Medicine classification. These were then considered to have level 2 of evidence, ranging from 2B (7.69\%) to 2C (92.31\%).

The synthesis of the articles selected by title, year of publication, outline, and outcome is shown in Chart 1.

Chart 1 - Summary of articles included in the review by title, year of publication, outline, and outcome, Belém, PA, Brazil, 2019

\begin{tabular}{|c|c|c|c|c|}
\hline Title and reference & $\begin{array}{c}\text { Year } \\
\text { Country }\end{array}$ & Outline & Intervention & Outcome \\
\hline $\begin{array}{l}\text { Spatial clustering of "measured" } \\
\text { and "unmeasured" risk factors for } \\
\text { HIV infections in hyper-endemic } \\
\text { communities in KwaZulu-Natal, } \\
\text { South Africa: results from } \\
\text { geoadditive models"(12) }\end{array}$ & $\begin{array}{l}2015 \\
\text { South } \\
\text { Africa }\end{array}$ & $\begin{array}{l}\text { Clinical trial } \\
\text { Ecological } \\
\text { study }\end{array}$ & $\begin{array}{l}\text { Biomedical HIV prevention } \\
\text { intervention; } \\
\text { Geoadditive models }\end{array}$ & $\begin{array}{l}\text { Spatial groups associated with low educational } \\
\text { level, early sexual activity, greater number of } \\
\text { sexual partners, not being married/living with a } \\
\text { sexual partner and sexual activity in exchange for } \\
\text { money, gifts, and drugs. }\end{array}$ \\
\hline $\begin{array}{l}\text { Characteristics of the HIV/AIDS } \\
\text { Epidemic in Women Aged 15-49 } \\
\text { Years from } 2005 \text { to } 2012 \text { in } \\
\text { China }^{(13)}\end{array}$ & $\begin{array}{l}2015 \\
\text { China }\end{array}$ & $\begin{array}{l}\text { Ecological } \\
\text { study }\end{array}$ & $\begin{array}{l}\text { Georeferencing and geocoding; } \\
\text { Spatial distribution analysis; } \\
\text { Global spatial autocorrelation analysis; } \\
\text { Local spatial autocorrelation analysis }\end{array}$ & $\begin{array}{l}\text { Increased rates in older women and non-marital } \\
\text { heterosexual contact as a very important factor } \\
\text { in the HIV and AIDS epidemic in women aged } 15 \\
\text { to } 49 \text { years. }\end{array}$ \\
\hline $\begin{array}{l}\text { Spatial analysis of infection by } \\
\text { the human immunodeficiency } \\
\text { virus among pregnant women }\end{array}$ & $\begin{array}{l}2015 \\
\text { Brazil }\end{array}$ & $\begin{array}{l}\text { Ecological } \\
\text { study }\end{array}$ & $\begin{array}{l}\text { Spatial distribution analysis; } \\
\text { Global spatial autocorrelation analysis; } \\
\text { Local spatial autocorrelation analysis }\end{array}$ & $\begin{array}{l}\text { Groupings of cases between disadvantaged } \\
\text { regions, correlated to illiteracy, absence of } \\
\text { prenatal care, and poverty. }\end{array}$ \\
\hline $\begin{array}{l}\text { Spatial dynamics of AIDS } \\
\text { incidence in the elderly in Rio de } \\
\text { Janeiro, Brazil, 1997-2011 }\end{array}$ & $\begin{array}{l}2015 \\
\text { Brazil }\end{array}$ & $\begin{array}{l}\text { Ecological } \\
\text { study }\end{array}$ & $\begin{array}{l}\text { Spatial distribution analysis; } \\
\text { Global spatial autocorrelation analysis; } \\
\text { Local spatial autocorrelation analysis; } \\
\text { Poisson regression }\end{array}$ & $\begin{array}{l}\text { Higher rates in regions of large cities, which may } \\
\text { be related to issues of having access to services } \\
\text { and knowledge of risks. }\end{array}$ \\
\hline $\begin{array}{l}\text { The spatial distribution pattern } \\
\text { of human immunodeficiency } \\
\text { virus/acquired immune } \\
\text { deficiency syndrome in China }{ }^{(16)}\end{array}$ & $\begin{array}{l}2016 \\
\text { China }\end{array}$ & $\begin{array}{l}\text { Ecological } \\
\text { study }\end{array}$ & $\begin{array}{l}\text { Spatial distribution analysis; } \\
\text { Global spatial autocorrelation analysis; } \\
\text { Local spatial autocorrelation analysis }\end{array}$ & $\begin{array}{l}\text { Higher proportion of cases associated with the } \\
\text { blood and blood products commerce, population } \\
\text { density, areas that constitute a route for drug } \\
\text { trafficking, as well as trade and travel borders. }\end{array}$ \\
\hline
\end{tabular}




\begin{tabular}{|c|c|c|c|c|}
\hline Title and reference & $\begin{array}{c}\text { Year } \\
\text { Country }\end{array}$ & Outline & Intervention & Outcome \\
\hline $\begin{array}{l}\text { Spatial Analysis of the Human } \\
\text { Immunodeficiency Virus } \\
\text { Epidemic among Men Who Have } \\
\text { Sex with Men in China, 2006- } \\
2015^{(17)}\end{array}$ & $\begin{array}{l}2017 \\
\text { China }\end{array}$ & $\begin{array}{l}\text { Ecological } \\
\text { study }\end{array}$ & $\begin{array}{l}\text { Cochran-Armitage test for trend; } \\
\text { Spatial distribution analysis; } \\
\text { Local spatial autocorrelation analysis } \\
\text { Spatial scan statistics; } \\
\text { Spatial Regression }\end{array}$ & $\begin{array}{l}\text { High rates for homosexual transmission, average } \\
\text { age between } 28 \text { and } 29 \text { years old, with higher } \\
\text { education level or above. Spatial spread of } \\
\text { infection groups among MSM from some large } \\
\text { cities in eastern China to most municipalities and } \\
\text { provincial capitals across the country. Positive } \\
\text { spatial autocorrelation between the numbers of } \\
\text { cases of the epidemic, population density, GDP per } \\
\text { capita and the number of medical institutions. }\end{array}$ \\
\hline $\begin{array}{l}\text { Location of Pre-exposure } \\
\text { Prophylaxis Services Across } \\
\text { New York City Neighborhoods: } \\
\text { Do Neighborhood Socio- } \\
\text { demographic Characteristics and } \\
\text { HIV Incidence Matter? }{ }^{(18)}\end{array}$ & $\begin{array}{l}2019 \\
\text { USA }\end{array}$ & $\begin{array}{l}\text { Ecological } \\
\text { study }\end{array}$ & $\begin{array}{l}\text { Georeferencing and geocoding; } \\
\text { Spatial distribution analysis; } \\
\text { Global spatial autocorrelation analysis; } \\
\text { Spearman's rank correlation coefficient; } \\
\text { Spatial Regression }\end{array}$ & $\begin{array}{l}\text { Absence of spatial autocorrelation between } \\
\text { race/ethnicity, income, insurance coverage, or } \\
\text { household of same-sex couples and the density of } \\
\text { local PrEP dispensers. Direct spatial autocorrelation } \\
\text { between PrEP providers and HIV incidence. }\end{array}$ \\
\hline $\begin{array}{l}\text { Spatial clusters of HIV-1 } \\
\text { genotypes in a recently infected } \\
\text { population in Yunnan, China }\end{array}$ & $\begin{array}{l}2019 \\
\text { China }\end{array}$ & $\begin{array}{l}\text { Cohort } \\
\text { study } \\
\text { Ecological } \\
\text { study }\end{array}$ & $\begin{array}{l}\text { Phylogenetic analysis; } \\
\text { Statistical analysis; } \\
\text { Spatial distribution analysis; } \\
\text { Spatial scan statistics }\end{array}$ & $\begin{array}{l}\text { Significant correlation between HIV infection, } \\
\text { women, and Chinese nationality. Positive spatial } \\
\text { autocorrelation between infection incidence, } \\
\text { heterosexual and homosexual contact, and } \\
\text { intravenous drug use. }\end{array}$ \\
\hline $\begin{array}{l}\text { Spatiotemporal analysis and } \\
\text { epidemiological characterization } \\
\text { of the human immunodeficiency } \\
\text { virus (HIV) in Libya within a } \\
\text { twenty five year period: } 1993- \\
2017^{(20)}\end{array}$ & $\begin{array}{l}2019 \\
\text { Libya }\end{array}$ & $\begin{array}{l}\text { Ecological } \\
\text { study }\end{array}$ & $\begin{array}{l}\text { Georeferencing and geocoding; } \\
\text { Spatial distribution analysis; } \\
\text { Spatial autocorrelation analysis; } \\
\text { Time trend analysis; } \\
\text { Spatial Regression }\end{array}$ & $\begin{array}{l}\text { Incidence associated with injectable drug use } \\
\text { and heterosexual activities. Positive spatial } \\
\text { autocorrelation on the Mediterranean coast } \\
\text { (Benghazi, Tripoli, and Musrata) and in Sabha, } \\
\text { in the middle of the Libyan desert, neighboring } \\
\text { countries of Sub-Saharan Africa. }\end{array}$ \\
\hline $\begin{array}{l}\text { Demographic characteristics } \\
\text { and spatial clusters of recent } \\
\text { HIV-1 infections among newly } \\
\text { diagnosed HIV-1 cases in Yunnan, } \\
\text { China, } 2015^{(21)}\end{array}$ & $\begin{array}{l}2019 \\
\text { China }\end{array}$ & $\begin{array}{l}\text { Ecological } \\
\text { study }\end{array}$ & Spatial scan statistics & $\begin{array}{l}\text { Higher proportion of infections in women, aged } \\
\text { less than } 25 \text { years and of secondary infection to } \\
\text { homosexual contact. Spatial clusters statistically } \\
\text { significant for the transmission of heterosexual } \\
\text { contacts, homosexual contacts, and for the use of } \\
\text { intravenous drugs. }\end{array}$ \\
\hline $\begin{array}{l}\text { Spatial clustering and socio- } \\
\text { demographic determinants of } \\
\text { HIV infection in Ethiopia, 2015- } \\
2017^{(22)}\end{array}$ & $\begin{array}{l}2019 \\
\text { Ethiopia }\end{array}$ & $\begin{array}{l}\text { Ecological } \\
\text { study }\end{array}$ & $\begin{array}{l}\text { Georeferencing and geocoding; } \\
\text { Global spatial autocorrelation analysis; } \\
\text { Local spatial autocorrelation analysis; } \\
\text { Spatial Regression }\end{array}$ & $\begin{array}{l}\text { Higher risk of infection in districts with a higher } \\
\text { proportion of migrants and individuals who } \\
\text { have never attended school. Space-hotspots in } \\
\text { highly agricultural areas that function as transport } \\
\text { corridors for truck drivers, with a large number } \\
\text { of other populations at risk for HIV, such as day } \\
\text { laborers during harvest time and sex workers. }\end{array}$ \\
\hline $\begin{array}{l}\text { Trend and spatial distribution of } \\
\text { infectious diseases in pregnant } \\
\text { women in the state of Paraná- } \\
\text { Brazil(23) }^{(23)}\end{array}$ & $\begin{array}{l}2019 \\
\text { Brazil }\end{array}$ & $\begin{array}{l}\text { Ecological } \\
\text { study }\end{array}$ & $\begin{array}{l}\text { Time trend analysis; } \\
\text { Spatial distribution analysis }\end{array}$ & $\begin{array}{l}\text { Constant increase associated with income, } \\
\text { inadequate prenatal care, multiple sexual partners, } \\
\text { black race/color, homosexuality, unprotected } \\
\text { sex, injectable drug use, blood transfusion and } \\
\text { accidents with sharp instruments in health } \\
\text { professionals. }\end{array}$ \\
\hline $\begin{array}{l}\text { A decade of sustained } \\
\text { geographic spread of HIV } \\
\text { infections among women in } \\
\text { Durban, South Africa }\end{array}$ & $\begin{array}{l}2019 \\
\text { South } \\
\text { Africa }\end{array}$ & $\begin{array}{l}\text { Ecological } \\
\text { study }\end{array}$ & Spatial Regression & $\begin{array}{l}\text { Higher probability in younger women, with two or } \\
\text { more sexual partners and that are not married, or } \\
\text { not cohabiting. }\end{array}$ \\
\hline
\end{tabular}

After analysis of the studies, social factors that influence the incidence of HIV infection emerged: gender, age, marital status, income, nationality, education, sexual activity initiation, as well as sexual relations, risky sexual behaviors, use of drugs, and knowledge of risks. As spatial factors, access to health services, demographic density, regions with highest poverty rates, with intense migratory flow, and border areas stood out.

\section{DISCUSSION}

In Brazil, the approach of the territory as a space of process and social construction was incorporated from the geographer Milton Santos, allowing epidemiology not only to confront the changes in the epidemiological profile secondary to globalization, but also to refute the approaches that disregarded the socio-spatial influences in the health and illness process ${ }^{(25)}$. In this sense, the findings of this integrative review point to the social conditions that, when associated with territorial ones, contribute to the incidence of HIV infection.

Then, there was an increase in incidence rates among females and young adults, as well as factors such as low socioeconomic conditions, sexual behaviors, and blood transfusions were pointed out in most publications as conducive to HIV infection. Studies do not show that the incidence of infection in men is greater than in women, however their active search for medical services, whether for routine HIV testing or for the detection 
of the virus during pregnancy and childbirth, may justify the proportion of cases in females. Additionally, the overall proportion of infections was higher in the population under 25 and decreased with age, suggesting that the time between infection and diagnosis is shorter in younger people ${ }^{(21)}$.

With regard to the aforementioned aspects, there is a slightly increasing trend in cases of HIV infection in older women, between 40 and 49 years of age, which may be related to the non-use of prevention methods, to an unconcern with their own fertility, the woman's submission to the partner who may resist using a condom, and risky sexual behaviors, such as nonmarital heterosexual contact, as a result of the search for sexual partners on the internet or sex tourism ${ }^{(13,26)}$.

From this perspective, a greater number of sexual partners, low or inconsistent condom use, not being married or not living with the sexual partner, as well as sexual activity in exchange for money, gifts, and drugs were common in the groups with the highest incidence of infection ${ }^{(12)}$, emerging knowledge of risk as one of the determinants of this process. It is inferred, therefore, that people with a good level of education may be more likely to use condoms compared to less educated people, which can help reduce HIV transmission ${ }^{(22)}$. On the other hand, among men who have sex with men (MSM), there is an increase in cases among individuals with a higher education level or above ${ }^{(17)}$.

Corroborating the above, there is an increase in infection rates due to homosexual practice and blood transfusions. Homosexuals, because they still experience stigma and prejudice for their sexuality, tend to move from their place of origin, where their identities are easily recognized by acquaintances, and disperse in several different capitals, easily building social networks as well as configuring the spatial spread of epidemic clusters among MSMs ${ }^{(17,21)}$. Regarding transfusions, the results may be associated with regions where the blood and blood products trade is allowed ${ }^{(16)}$.

Also, a higher incidence in black populations is identified, this occurrence being attributed to the erroneous conception of association between the brown and black population to social vulnerability, to the global impoverishment of the epidemic and to the difficulty of access to health services, since race/color of an individual, by itself, does not determine social status ${ }^{(23,27)}$.

As spatial determinants, cities with high population density and consequent unequal access to health services, regions with higher levels of poverty and border areas and with a higher proportion of migrants, which function as large corridors for the circulation of people, among them, truckers and sex workers. It is added that these borders favor the drug trade, as is the case in Yunnan, China, which neighbors Sichuan, where there is an active trade in narcotics and low socioeconomic development, another determinant of the incidence of HIV infection. In Sichuan, there is a large outflow of rural residents, generally with a lower education, to places like Yunnan, in search of income-generating activities, such as sex work, which can take on drug addiction habits and thus, increase the vulnerability to HIV infection ${ }^{(13,17,22)}$.

As for access to services, this is presented not only as a determinant for the incidence of HIV infection, but also for the mortality from AIDS-related causes. In this sense, a study involving the elderly indicated that the highest rates of infection and disease were concentrated in the large cities of Niterói and Rio de Janeiro, where disparities in the provision of services contribute to late access to diagnosis and treatment of HIV infection ${ }^{(15,28)}$.

The evidence in this review indicates that social and spatial behaviors have increased vulnerability to HIV infection, requiring monitoring of areas and populations characterized by the highest proportion of cases, in order to target more focused and efficient prevention strategies to fight the virus. In this sense, it is recommended to guarantee sufficient access to good quality health services, as well as public health campaigns.

\section{Study limitations}

Among the limitations of the study, the selection of only primary studies, with language restriction and temporal cut, stands out, reducing the quality of the evidence. An additional limitation would be the fact that other databases have not been investigated, leading to the non-inclusion of other scientific articles.

\section{Contributions to the field of nursing, health, or public policy}

By showing socio-spatial determinants associated with the incidence of HIV infection, it is possible to identify populations at higher risk of infection due to geographical, social, educational, or behavioral factors, and these results can support the planning, evaluation, and decision-making of health administrators and professionals regarding the need for rapid intervention.

\section{FINAL CONSIDERATIONS}

The relevance of spatial analysis techniques for health studies is confirmed, considering that it allows not only to map the distribution of diseases, but also to understand the influence of determinant and conditioning factors of the health-disease process.

The influence of regional inequalities, whether socioeconomic or spatial, is revealed by the incidence of HIV infection. In this sense, there is also the interest of researchers in studies that involve socio-spatial aspects associated with HIV infection, expanding the simple conception of territory just as a physical space. The territory then becomes a space for building personal, historical, political, and economic relationships.

Finally, it is recommended to develop new studies on the topic, in different regions of the country, in order to direct prevention and control actions, as well as the consequent reduction of HIV infection, considering that the regional rates of detection of new HIV infections in Brazil do not follow the national reduction.

\section{FUNDING}

The study was supported by the Coordenação de Aperfeiçoamento de Pessoal de Nível Superior under grant number $88881.200527 / 2018-01$, PROCAD-AM. 


\section{REFERENCES}

1. Programa Conjunto das Nações Unidas sobre HIV/AIDS - UNAIDS (Brasil). Relatório informativo. Brasília (DF); 2018.

2. Pareja JMD, Guerra FF, Vieira SR, Teixeira KMD. A produção do espaço e sua relação no processo de saúde - doença familiar. Saude Soc. 2016;25(1):133-44. https://doi.org/10.1590/S0104-12902016152797.

3. Egry EY. A Glance at the Good Practices of Nursing in Primary Care. Rev Bras Enferm. 2018;71(3):930-1. https://doi. org/10.1590/0034-7167.2018710301

4. Carrapato P, Correia P, Garcia B. Determinante da saúde no Brasil: a procura da equidade na saúde. Saude Soc. 2017;26(3):676-89. https://doi. org/10.1590/S0104-12902017170304

5. Guimaraes RB. Geografia e saúde coletiva no Brasil. Saúde Soc. 2016;25(4):869-79. https://doi.org/10.1590/S0104-12902016167769

6. Mendes KDS, Silveira RCCP, Galvão CM. Revisão integrativa: método de pesquisa para a incorporação de evidências na saúde e na enfermagem. Texto Contexto Enferm. 2008;17(4):758-764. https://doi.org/10.1590/s0104-07072008000400018

7. Santos CM, Pimenta CA, Nobre R. The PICO strategy for the research question construction and evidence search. Rev Latino-Am Enfermagem. 2007;15(3):508-11. https://doi.org/10.1590/\$0104-11692007000300023

8. Ministério da Saúde (BR). Portaria n. ${ }^{\circ}$ 1.271, de 6 de junho de 2014. Define a Lista Nacional de Notificação Compulsória de doenças, agravos e eventos de saúde pública nos serviços de saúde públicos e privados em todo o território nacional, nos termos do anexo, e dá outras providências. Diário Oficial da União, Brasília: Ministério da Saúde; 2014.

9. Ouzzani M, Hammady H, Fedorowicz Z, Elmagarmind A. Rayyan-a web and mobile app for systematic reviews. BioMed Central. 2016;5(1):210. https://doi.org/10.1186/s13643-016-0384-4

10. Moher D, Liberati A, Tetzlaff J, Altman DG, PRISMA Group. Preferred reporting items for systematic reviews and meta-analyses: the PRISMA Statement. PLoS Med. 2009;6(7):e1000097. https://doi.org/10.1371/journal.pmed1000097

11. Ursi ES, Gavao CM. Prevenção de lesões de pele no perioperatório: revisão integrativa da literatura. Rev Latino-Am Enfermagem. 2006;14(1):124-31. https://doi.org/10.1590/S0104-11692006000100017

12. Wand H, Ramjee G. Spatial clustering of "measured" and "unmeasured" risk factors for HIV infections in hyper-endemic communities in KwaZulu-Natal, South Africa: results from geoadditive models. AIDS Care. 2015;27(11):1375-81. https://doi.org/10.1080/09540121.2015.109 6896

13. Zhang XY, Huang T, Feng YB, Li M, Chen FF, Li Yg, et al. Characteristics of the HIV/AIDS epidemic in women aged $15-49$ years from 2005 to 2012 in China. Biomed Environ Sci. 2015;28(10):701-8. https://doi.org/10.3967/bes2015.100

14. Holanda ER, Galvão MTG, Pedrosa NL, Paiva SS, Almeida RLF. Spatial analysis of infection by the human immunodeficiency virus among pregnant women. Rev Latino-Am Enfermagem. 2015;23(3):441-9. https://doi.org/10.1590/0104-1169.0481.2574

15. Rodrigues NCP, Almeida AS, Braga JU, O'Dwyer G, Apratto Jr PC, Daumas RP, et al. Spatial dynamics of AIDS incidence in the elderly in Rio de Janeiro, Brazil, 1997-2011. Cad Saúde Pública. 2015;31(8):1721-1731. https://doi.org/10.1590/0102-311X00152914

16. Wang $Y$, Shi X, Shi N, Yang Y, Mao S, Hui X. The spatial distribution pattern of human immunodeficiency virus/acquired immune deficiency syndrome in China. Geospat Health. 2016;11(414):104-9. https://doi.org/10.4081/gh.2016.414

17. Qin Q, Guo W, Tang W, Mahapatra T, Wang L, Zhang N, et al. Spatial analysis of the human immunodeficiency virus epidemic among men who have sex with men in China, 2006-2015. Clin Infect Dis. 2017;64(7):956-963. https://doi.org/10.1093/cid/cix031

18. Kim B, Callander D, DiClemente R, Trinh-Shevrin C, Thorpe LE, Duncan DT. Location of pre-exposure prophylaxis services across New York City neighborhoods: do neighborhood socio-demographic characteristics and HIV incidence matter? AIDS Behav. 2019;23(10):2795-802. https://doi.org/10.1007/s10461-019-02609-2

19. Chen M, Ma Y, Chen H, Dai J, Luo H, Yang C, et al. Spatial clusters of HIV-1 genotypes in a recently infected population in Yunnan, China. BMC Infect Dis 2019;19(669). https://doi.org/10.1186/s12879-019-4276-9

20. Daw MA, Daw AM, Sifennasr NEM, Draha AM, Daw AA, Daw AA, et al. Spatiotemporal analysis and epidemiological characterization of the human immunodeficiency virus (HIV) in Libya within a twenty five year period: 1993-2017. AIDS Res Ther. 2019;16(1):14. https://doi. org/10.1186/s12981-019-0228-0

21. Chen M, Ma Y, Chen H, Dai J, Luo H, Yang C, et al. Demographic characteristics and spatial clusters of recent HIV-1 infections among newly diagnosed HIV-1 cases in Yunnan, China, 2015. BMC Public Health. 2019;19(1507). https://doi.org/10.1186/s12889-019-7557-8

22. Gelaw YA, Magalhaes RJS, Assefa Y, Williams G. Spatial clustering and socio-demographic determinants of HIV infection in Ethiopia, 20152017. Int J Infect Dis. 2019;82:33-39. https://doi.org/10.1016/j.ijid.2019.02.046

23. Falavina LP, Lentsck MH, Mathias TAF. Trend and spatial distribution of infectious diseases in pregnant women in the state of Paraná-Brazil. Rev Latino-Am Enfermagem. 2019;27:e3160. https://doi.org/10.1590/1518-8345.2838.3160

24. Ramjee G, Sartorius B, Morris N, Wand H, Reddy T, Yssel JD, et al. A decade of sustained geographic spread of HIV infections among women in Durban, South Africa. BMC Infect Dis 2019;19(500). https://doi.org/10.1186/s12879-019-4080-6 
25. Furtado JP, Oda WY, Borysow IC, Kapp S. The concept of territory in mental health. Cad Saúde Pública. 2016;32(9):e00059116. https://doi. org/10.1590/0102-311×00059116

26. Mor Z, Sheffer R, Chemtob D. Causes of death and mortality trends of all individuals reported with HIV/AIDS in Israel, 1985-2010. J. Public Health. 2017;40(1):56-64. https://doi.org/10.1093/pubmed/fdx039

27. Galvão JMV, Costa ACM, Galvão JV. Demographic and socio-demographic profile of people living with HIV/aids. Rev Enferm UFPI. 2017;6(1):4-8. https://doi.org/10.26694/reufpi.v6i1.5533

28. Pereira GFM, Shimizu HE, Bermudez XP, Hamann EM. Epidemiology of HIV and AIDS in the state of Rio Grande do Sul, Brazil, $1980-2015$. Epidemiol Serv Saude. 2018;27(4):e2017374. https://doi.org/10.5123/S1679-49742018000400004 